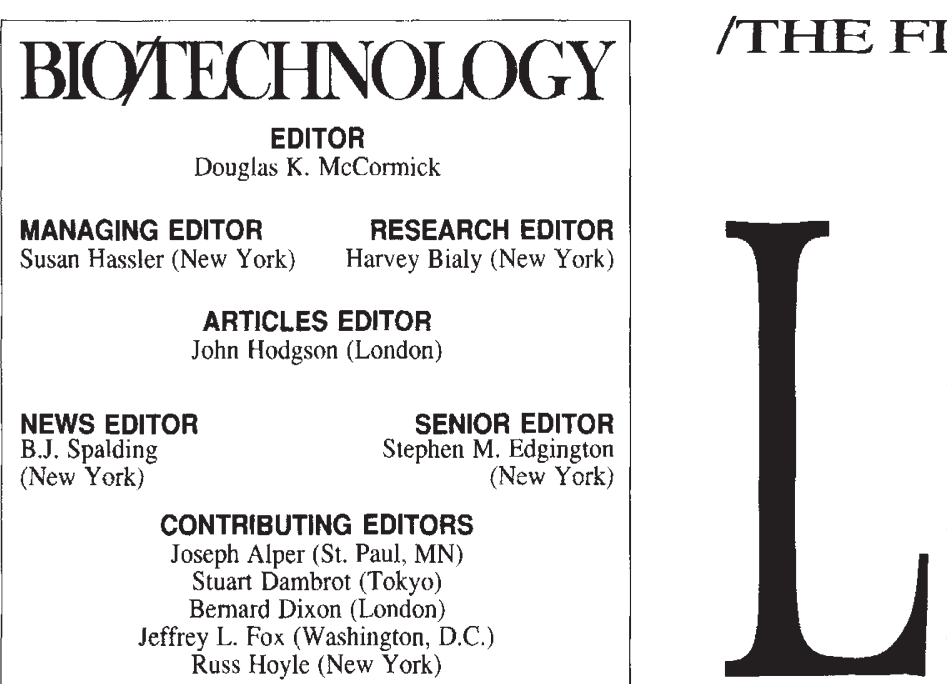

EDITORIAL ASSISTANT

Claire M. Corcoran

ART DIRECTOR

ASST. ART DIRECTOR Lou Pippo

\begin{tabular}{|c|c|}
\hline \multicolumn{2}{|r|}{ 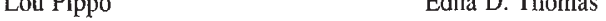 } \\
\hline \multicolumn{2}{|c|}{$\begin{array}{l}\text { PUBLISHER } \\
\text { Andy Sutheriand }\end{array}$} \\
\hline \multicolumn{2}{|c|}{$\begin{array}{c}\text { VICE PRESIDENT - SALES } \\
\text { Marion Delaney }\end{array}$} \\
\hline \multicolumn{2}{|c|}{$\begin{array}{c}\text { ADVERTISING SALES MANAGERS } \\
\text { Marianne S. Ettisch (Classified, U.S.) } \\
\text { Angela Kays (Europe) } \\
\text { Stephanie J. Nolan (U.S.) } \\
\text { Julie Skeet (Classified, Europe) }\end{array}$} \\
\hline \multicolumn{2}{|c|}{$\begin{array}{l}\text { VICE PRESIDENT } \\
\text { MARKETING AND PRODUCTION } \\
\text { James Skowrenski }\end{array}$} \\
\hline $\begin{array}{l}\text { MARKETING } \\
\text { MANAGER } \\
\text { Bruce Shriver, Jr. }\end{array}$ & $\begin{array}{r}\text { PRODUCTION } \\
\text { MANAGER } \\
\text { Estelle B. Selzer }\end{array}$ \\
\hline $\begin{array}{r}\text { 65 Bleecker } S \\
\text { Tel: }(212) 477- \\
\text { Editorial Fax: }(212)\end{array}$ & $\begin{array}{l}\text { W YORK } \\
\text { New York, NY } 10012 \\
500 \text { Fax: (212) 505-1364 } \\
\text { 54-9493 MCI ID \#: } 329-8956\end{array}$ \\
\hline $\begin{array}{l}4 \text { Little Essex } \\
\text { Tel: }(071) 872-\end{array}$ & $\begin{array}{l}\text { ONDON } \\
\text { t., London WC } 2 \text { R } 3 \mathrm{LF} \\
103 \text { Fax }(071) 240-2408\end{array}$ \\
\hline SCIENTIFIC ADVIS & RY BOARD \\
\hline $\begin{array}{l}\text { George Poste } \\
\text { Ken-ichi Arai } \\
\text { Teruhiko Beppu } \\
\text { Ronald E. Cape } \\
\text { Jean-Pierre Changeux } \\
\text { Mary-Dell Chilton } \\
\text { Nam-Hai Chua } \\
\text { Rita R. Colwell } \\
\text { Arnold Demain }\end{array}$ & $\begin{array}{l}\text { SmithKline Beecham } \\
\text { DNAX Research Institute } \\
\text { University of Tokyo } \\
\text { Darwin Molecular Technologies } \\
\text { Institut Pasteur } \\
\text { CIBA-Geigy } \\
\text { Rockefeller University } \\
\text { Maryland Biotechnology Institute } \\
\text { Massachusetts Institute of } \\
\text { Technology }\end{array}$ \\
\hline $\begin{array}{l}\text { J. Lawrence Fox } \\
\text { David Goeddel } \\
\text { Leroy Hood } \\
\text { Morio Ikehara }\end{array}$ & $\begin{array}{l}\text { Amoco Technology } \\
\text { Genentech } \\
\text { California Institute of Technology } \\
\text { Protein Engineering Research } \\
\text { Institute }\end{array}$ \\
\hline $\begin{array}{l}\text { Ernest Jaworski } \\
\text { Irving Johnson } \\
\text { David Mount } \\
\text { Victor Nussenzweig }\end{array}$ & $\begin{array}{l}\text { Monsanto Company } \\
\text { Consultant } \\
\text { University of Arizona } \\
\text { New York University Medical } \\
\text { Center }\end{array}$ \\
\hline $\begin{array}{l}\text { George Rose } \\
\text { Carl-Gustaf Rosen } \\
\text { Kendall Smith } \\
\text { Yukio Sugino } \\
\text { Marc Van Montagu } \\
\text { Indra K. Vasil } \\
\text { Wataru Yamaya } \\
\text { Douglas Youvan }\end{array}$ & $\begin{array}{l}\text { Washington University } \\
\text { Abitec AB } \\
\text { Dartmouth Medical School } \\
\text { Takeda Chemicals } \\
\text { Plant Genetic Systems } \\
\text { University of Florida } \\
\text { Seikagaku Kogyo } \\
\text { Massachusets Institute of } \\
\text { Technology }\end{array}$ \\
\hline
\end{tabular}

\section{Please, Mr. Clinton}

ast month, we started off a list of recommendations-pleas, we called them-to the incoming (incumbent, by the time this sees print) U.S. administration. We started with two points:

Look at benefits when you look at health-care costs. Consider gains in productivity and quality of life as well as direct medical costs when you assess the value of expensive, new (i.e., bio-) technology.

Preserve the Orphan Drug Act. Science and market forces will conspire to divide most drug markets into ever-narrower molecular indications. Someday, perhaps, most drugs may be orphans, and we need to secure that R\&D effort.

This month, we add a few new points.

Be careful of old reflexes. Back in 1983, then-Representative Al Gore was the most prominent of the legislators profiled in our first issue ("How the New Congress will Legislate Biotech," Bio/Technology 1:26-29, March, 1983). Mr. Gore's oversight subcommittee of the House Science and Technology Committee showed a strong disposition to regulate anything in sight. (At one meeting a few years later, we remember, Mr. Gore explained the tendency this way, "When the only tool you have is a hammer, every problem looks like a nail.") The Congressman's staff recommended committees to control human gene therapy, rules on biotech-based diagnostics and genetic screening, and even proposed that university researchers be prohibited from holding equity in commercial ventures. Gore's staffers were among the most active in trying to formulate across-the-board regulations of agricultural and environmental biotechnology as biotechnology. As Russ Hoyle pointed out in his commentary last month ("Will Clinton/Gore Roll Back Recombinants?"), that impulse seems to live on.

It should not.

Remember that research is not product development. There is no telling where the really important discoveries will come from. If we start setting up committees to ask not only "Is this good science?" but also "Is this commercially viable?" we will cut our own throats-securing, perhaps, efficient incremental progress along the broad avenues already trodden down by consensus, but at the cost (also perhaps) of the truly new, the fundamental, the earth-shaking. Bureaucracy loves mediocrity; that is both its flaw and its virtue. Exploration is not its natural function. Civilian basic research is a higgledy-piggledy affair. At its best, it supports thousands of really bright people as they poke around in some really interesting stuff-scarcely a function with which a goals-and-objectives policymaker can be comfortable. Yet this chaos has proved to be a research powerhouse, driving the world's only considerable venture capital engine to throw off new ideas and new industries at a rate unequalled anywhere. Please think carefully before putting a governor on this dynamo.

Make sure U.S. patents have international teeth. As we've noted before ("Rethinking First-to-Invent," Bio/Technology 10:1383, November 1992), the U.S. will be giving up quite a bit if it adopts the international first-to-file patent system. Be certain that in the exchange that true innovators find sufficient protectionfrom piratical offshore competitors and (via patent extensions) from the long, dead times between regulatory submission and market approval - not only in pharmaceuticals, but also in the agriculture and agrichemicals, where some registrations can take almost as long and cost almost as much.

It may now be a moot point, but keep David Kessler. Not because he is a defender of biotechnology - that does not appear to be among his priorities--but because he has, in a remarkably short time, taken a dispirited, defanged U.S. Food and Drug Administration and turned it into what appears to be a tough, innovative unit dedicated to protecting public health by tough enforcement and by taking creative measures that get medicines to the patients who need them as quickly as is consistent with safety. 